\title{
STRATEGI PENGATURAN DIRI DALAM BELAJAR SEBAGAI MEDIATOR HARAPAN ORANG TUA DAN MOTIVASI INTRINSIK TERHADAP PRESTASI AKADEMIK
}

\author{
Leni Novita ${ }^{1^{*}}$, Melly Latifah ${ }^{1)}$ \\ ${ }^{1}$ Departemen IImu Keluarga dan Konsumen, Fakultas Ekologi Manusia, Institut Pertanian Bogor \\ Bogor 16680, Indonesia \\ ${ }^{\star}$ E-mail: leniiec@yahoo.com
}

\begin{abstract}
Abstrak
Berbagai faktor telah ditemukan untuk menjelaskan pengaruhnya terhadap prestasi akademik siswa baik itu faktor internal maupun eksternal siswa. Hanya saja kajian yang menjelaskan secara komprehensif kedua faktor tersebut dalam memberikan pengaruhnya secara bersama-sama terhadap prestasi akademik masih jarang dilakukan. Penelitian ini bertujuan untuk menganalisis pengaruh karakteristik anak dan keluarga, harapan orang tua, motivasi intrinsik, dan strategi pengaturan diri dalam belajar terhadap prestasi akademik siswa Sekolah Menengah Pertama (SMP). Penelitian dilakukan pada 149 anak kelas VIII SMPN di Bogor yang dipilih dengan menggunakan metode penarikan contoh acak dari seluruh siswa kelas VIII di sekolah terpilih. Penelitian ini menemukan bahwa harapan orang tua memiliki pengaruh positif terhadap motivasi intrinsik, dan motivasi intrinsik memiliki pengaruh positif terhadap strategi pengaturan diri dalam belajar. Strategi pengaturan diri dalam belajar memiliki pengaruh positif terhadap prestasi akademik. Pada penelitian ini, strategi pengaturan diri dalam belajar berperan sebagai mediator antara pengaruh harapan orang tua dan motivasi intrinsik terhadap prestasi akademik. Oleh karenanya, orang tua dan guru harus mampu membangkitkan motivasi intrinsik siswa sehingga siswa dapat melakukan strategi pengaturan diri dalam belajar secara baik untuk meningkatkan prestasi akademiknya.
\end{abstract}

Kata kunci: harapan orang tua, motivasi intrinsik, prestasi akademik, strategi pengaturan diri dalam belajar

\section{The Role of Self-Regulated Learning Strategies: Mediator Variable for Parents Expectation and Intrinsic Motivation towards Academic Achievement}

\begin{abstract}
Some factors had been found to explain its effect on student achievement both internal and external factors of students. The comprehensive study that explains these two factors in giving effect jointly to academic achievement is still limited. This study examined the effects of child and family characteristics, parent's expectation, intrinsic motivation, and self-regulated learning strategies on academic achievement of junior high school. The samples of this study were selected by random sampling. One hundred and forty nine of junior high school students in Bogor, 8th grade, were selectedas samples in this study. This study found that parents expectation were positively affecting intrinsic motivation and intrinsic motivation were positively affecting selfregulated learning strategies. Self-regulated learning strategies were positively affecting academic achievement. Self-regulated learning strategies were found as mediator for the effect of parent's expectation and intrinsic motivation towards academic achievement. Therefore, parents and teachers should be able to raise the intrinsic motivation of students so that students can perform self-regulated learning strategies that can improve their academic achievement.
\end{abstract}

Keywords: academic achievement, intrinsic motivation, parents expectation, self-regulated learning strategies

\section{PENDAHULUAN}

Perhatian publik terhadap prestasi akademik sudah berlangsung sejak 20 tahun terakhir. Perhatian ini semakin terlihat ketika sistem pendidikan Amerika mengembangkan dan mengimplementasikan kebijakan standar pendidikan dengan fokus utamanya adalah meningkatkan pencapaian prestasi akademik siswa (Weiss, 2008). Indonesia juga memiliki standar pendidikan yang tertuang dalam undang-undang. Ketertarikan dunia terhadap prestasi akademik juga terlihat dari dilakukannya pengukuran prestasi akademik yang berskala internasional. Programme for International Student Assessment (PISA) merupakan sebuah program internasional yang bertujuan untuk menilai pengetahuan dan 
kemampuan anak usia 15 tahun. Data PISA tahun 2009 dan 2012 memperlihatkan bahwa dalam kurun waktu tiga tahun siswa Indonesia masih belum mampu meningkatkan performanya di bidang membaca, sains, dan matematika (OECD, 2012). Beberapa penelitian telah dilakukan untuk mengetahui faktor-faktor yang dapat memengaruhi pencapaian prestasi akademik siswa. Harapan orang tua memiliki pengaruh positif terhadap prestasi siswa (Kaplan et al., 2001; Yang, Tseng, dan Lin, 2012). Harapan orang tua mampu meningkatkan motivasi intrinsik anak untuk terlibat dalam suatu aktivitas (Yamamoto \& Holloway, 2010). Motivasi intrinsik memiliki pengaruh positif terhadap pencapaian prestasi anak (Yang, Tseng, \& Lin, 2012). Siswa yang termotivasi secara intrinsik akan menggunakan berbagai strategi dalam belajar yang dapat menjaga tingkat ketertarikan dan perhatian terhadap materi pelajaran (Metallidou \& Vlachou, 2010). Zimmerman (1990) menuliskan bahwa strategi pengaturan diri dalam belajar (self-regulated learning strategies) adalah proses dan aktivitas yang diarahkan untuk memperoleh pengetahuan atau kemampuan yang melibatkan persepsi dan tujuan pembelajaran. Strategi pengaturan diri dalam belajar yang diterapkan oleh siswa berpengaruh langsung dan signifikan terhadap prestasi akademik siswa (Salmeron-Perez et al., 2010). Siswa yang memiliki strategi dalam belajar lebih cenderung untuk pantang menyerah ketika menghadapi berbagai tugas dan tantangan yang sulit (Thongnoum, 2002).

Akan tetapi, beberapa penelitian lainnya menunjukkan hasil yang berbeda dalam membuktikan pengaruh harapan orang tua, motivasi intrinsik, dan strategi pengaturan diri dalam belajar terhadap prestasi akademik. Hasil penelitian Liao et al. (2012) menunjukkan bahwa motivasi intrinsik tidak memiliki pengaruh langsung terhadap prestasi akademik siswa. Hasil penelitian Novariandhini \& Latifah (2012) menemukan bahwa motivasi intrinsik memiliki hubungan negatif dengan tingkat prestasi siswa. Hasil penelitian Agliata (2005) memperlihatkan bahwa siswa mengalami tingkat depresi dan kecemasan yang tinggi, serta tingkat kepercayaan diri (self-esteem) yang rendah ketika terjadi ketidaksesuaian antara harapan orang tua dengan kenyataan yang dirasakan siswa. Sasikala dan Karunanidhi (2011) menuliskan bahwa harapan orang tua merupakan sumber stres utama pada siswa di tingkat pendidikan menengah di Asia. Hal ini memperlihatkan adanya kekosongan yang harus diisi dari hasil penelitian terdahulu mengenai pengaruh harapan orang tua, motivasi intrinsik, dan strategi pengaturan diri dalam belajar terhadap prestasi akademik. Oleh karena itu, penelitian ini dilakukan untuk menjawab pertanyaan: (1) harapan orang tua yang bagaimana yang mampu untuk meningkatkan prestasi akademik? dan (2) bagimana peran motivasi intrinsik dalam meningkatkan prestasi akademik.

Penelitian ini dilakukan pada anak usia remaja dikarenakan oleh beberapa hal: (1) diketahui bahwa kemampuan penggunaan strategi pengaturan diri dalam belajar mulai muncul pada usia remaja (Salmeron-Perez et al., 2010), (2) remaja mulai mampu untuk menggunakan berbagai strategi dalam meningkatkan prestasi (Friedenberg \& Breckenridge, 2005), (3) diketahui bahwa perkembangan mental, emosi dan sosial remaja secara signifikan dipengaruhi oleh orang tua (Sasikala \& Karunanidhi, 2001), dan (4) remaja mulai mengembangkan pemahaman dan cara berpikir mengenai diri sendiri dan orang lain (Friedenberg \& Breckenridge, 2005). Berdasarkan perumusan tersebut, penelitian ini bertujuan untuk menganalisis pengaruh harapan orang tua, motivasi intrinsik, dan strategi pengaturan diri dalam belajar terhadap prestasi akademik.

\section{METODE}

Penelitian ini menggunakan desain cross sectional, yang dilakukan di Wilayah Bogor, Provinsi Jawa Barat. Metode cluster random sampling digunakan untuk menetapkan lokasi penelitian dengan membagi wilayah penelitian menjadi Kota dan Kabupaten Bogor, yaitu SMPN X di Kota Bogor dan SMPN $Y$ di Kabupaten Bogor. Penelitian ini dilaksanakan mulai bulan Maret sampai dengan bulan Mei 2014. Populasi penelitian ini adalah seluruh siswa di sekolah yang menjadi lokasi terpilih. Kerangka contoh penelitian ini adalah siswa kelas VIII di sekolah terpilih. Jumlah contoh pada penelitian ini adalah 149 anak yang dipilih secara acak dari kerangka contoh.

Data primer diperoleh melalui pengisian kuesioner yang berisi variabel-variabel yang akan diteliti. Data primer dari kuesioner penelitian meliputi karakteristik anak (usia dan jenis kelamin), karakteristik keluarga (usia orang tua, pendidikan orang tua, dan pendapatan orang tua), harapan orang tua, 
motivasi intrinsik, dan strategi pengaturan diri dalam belajar.

Kuesioner harapan orang tua dimodifikasi
dari instrumen Perception of Parental Expectations Inventory yang dikembangkan oleh Sasikala dan Karunanidhi (2011). Kuesioner ini terdiri atas 22 pernyataan yang terbagi ke dalam empat dimensi yaitu harapan pribadi, harapan akademik, harapan karir, dan ambisi orang tua. Kuesioner ini menggunakan skala jawaban Likert 1-4 (1= "sangat tidak setuju"; 2= "tidak setuju"; 3= "setuju"; dan 4= "sangat setuju") dengan nilai reliabilitas sebesar 0,795 . Kuesioner motivasi intrinsik dimodifikasi dari instrumen Intrinsic Motivation Inventory (SDT, 2014). Kuesioner ini terdiri atas 25 pernyataan yang terbagi ke dalam enam dimensi yaitu ketertarikan atau kesenangan, persespi terhadap kemampuan, usaha atau prioritas, tekanan atau ketegangan, persepsi terhadap pilihan, dan nilai atau kegunaan. Kuesioner ini menggunakan skala jawaban Likert 1-4 (1= "sangat tidak setuju"; 2= "tidak setuju"; $3=$ "setuju"; dan $4=$ "sangat setuju") dengan nilai reliabilitas sebesar 0,835. Kuesioner strategi pengaturan diri dalam belajar dimodifikasi dari instrumen Motivated Strategies for Learning Questionnaire (MSLQ) yang dikembangkan oleh Pintrich et al. (1991). Kuesioner ini terdiri atas 34 pernyataan yang terbagi ke dalam sembilan dimensi yaitu rehearsal, elaboration, organization, critical thinking, metacognitive self-regulation, time/study environmental management, effort regulation, peer learning, dan help seeking. Kuesioner ini menggunakan skala jawaban Likert 1-4 (1= "sangat tidak sesuai"; $2=$ "tidak sesuai"; $3=$ "sesuai"; dan $4=$ "sangat sesuai") dengan nilai reliabilitas sebesar 0,848 .

Data skor pada variabel harapan orang tua, motivasi intrinsik, dan strategi pengaturan diri dalam belajar dijumlahkan dan dihitung indeksnya. Selanjutnya, indeks harapan orang tua dan motivasi intrinsik dikelompokkan menjadi tiga kategori, yaitu rendah $(<60)$, sedang (60-80), dan tinggi (>80). Prestasi akademik anak dikelompokkan ke dalam empat kategori sesuai dengan Permendikbud No $81 \mathrm{~A}$ Tahun 2013 yaitu kurang $(\leq 2,49)$, cukup $(2,50$ $2,99)$, baik $(3,00-3,49)$, dan sangat baik $(3,50$ $4,00)$.

Analisis data yang digunakan meliputi analisis deskriptif (frekuensi, rata-rata dan standar deviasi) dan analisis Partial Least Square (PLS). Analisis deskriptif dilakukan untuk melihat sebaran data karakteristik anak dan orang tua, harapan orang tua, motivasi intrinsik, strategi pengaturan diri dalam belajar, serta prestasi akademik. Analisis PLS digunakan untuk melihat pengaruh langsung dan tidak angsung variabel independen (harapan orang tua, motivasi intrinsik dan strategi pengaturan diri dalam belajar) terhadap variabel dependen (prestasi akademik).

Pengaruh antarvariabel dinyatakan signifikan ketika memiliki nilai t-hitung $>1,96$. Hal yang perlu diperhatikan dalam melakukan pengujian menggunakan alat statistik PLS adalah evaluasi goodness of fit, yaitu pengujian pada outer model (outer loading, Average Variance Extracted, dan composite reliability) dan inner model ( $R$-square). Nilai outer loading digunakan untuk melihat validitas indikator dari variabel yang diteliti. Nilai outer loading $>0,5$ menunjukkan bahwa indikator valid dalam menggambarkan variabelnya. Nilai Average Variance Extracted (AVE) digunakan untuk melihat validitas dari suatu variabel. Nilai AVE $>0,5$ menunjukkan bahwa variabel penelitian sudah valid. Nilai composite reliability digunakan untuk melihat konsistensi dari suatu variabel. Nilai composite reliability $>0,7$ menunjukkan bahwa variabel penelitiaan konsisten. Inner model digunakan untuk melihat keragaman suatu variabel yang dapat dijelaskan oleh variabel lain dengan melihat nilai $R$-square dari variabel tersebut. Pada penelitian ini, semua data yang akan dianalisis secara parsial telah memenuhi persyaratan penggunaan alat statistik PLS.

\section{HASIL}

\section{Karakteristik Anak dan Keluarga}

Sekitar 59 persen anak pada penelitian ini berjenis kelamin perempuan dengan usia 12-15 tahun. Rata-rata usia ayah adalah sekitar 46 tahun, dan rata-rata usia ibu adalah sekitar 42 tahun. Lebih dari separuh ayah $(52,0 \%)$ dan ibu $(57,0 \%)$ memiliki lama pendidikan setara dengan tamatan Sekolah Menengah Atas (SMA). Sebagian besar anak $(82,0 \%)$ berada pada keluarga dengan pendapatan per kapita per bulan di atas garis kemiskinan atau masuk ke dalam kategori tidak miskin. Rata-rata pendapatan per kapita per bulan keluarga pada penelitian ini adalah Rp867.079 (BPS, 2011; batas garis kemiskinan Kota Bogor=Rp305.870; batas garis kemiskinan Kabupaten Bogor=Rp235.682). 


\section{Harapan Orang Tua}

Hasil penelitian menunjukkan bahwa lebih dari separuh anak $(65,1 \%)$ mempersepsikan harapan orang tua ke dalam kategori sedang, dengan rata-rata indeks harapan orang tua sebesar 73,8. Artinya, lebih dari separuh anak pada penelitian ini memiliki persepsi bahwa orang tua cukup memiliki harapan terhadap kesuksesan anak di masa depan. Sementara itu, hanya 29,5 persen yang mempersepsikan orang tua mempunyai harapan tinggi terhadap mereka. Selain itu, masih ada 5,4 persen anak yang merasa bahwa orang tuanya mempunyai harapan yang rendah terhadap dirinya. Hasil lain juga menunjukkan bahwa 41,6 persen anak memiliki persepsi bahwa harapan karir sebagai harapan yang paling banyak dimiliki orang tua. Harapan pribadi menjadi dimensi harapan orang tua kedua terbanyak yang dipersepsikan anak dimiliki orang tua $(38,9 \%)$. Harapan pribadi dan karir adalah dimensi harapan orang tua ketiga terbanyak yang dipersepsikan anak dimiliki orang tua $(10,7 \%)$.

\section{Motivasi Intrinsik}

Lebih dari separuh anak (53,0\%) memiliki motivasi intrinsik yang masuk ke dalam kategori sedang, dengan rata-rata skor motivasi intrinsik sebesar 60,52. Artinya, lebih dari separuh anak pada penelitian ini memiliki persepsi bahwa mereka memiliki motivasi intrinsik yang cukup untuk membuat mereka terlibat dalam aktivitas pembelajaran. Pada penelitian ini, 90 persen anak memiliki persepsi bahwa usaha atau prioritas adalah dimensi motivasi intrinsik yang paling banyak menyebabkan anak terlibat di dalam suatu aktivitas atau kegiatan pembelajaran. Nilai atau kegunaan menjadi dimensi motivasi intrinsik kedua terbanyak yang dimiliki anak (89,0\%). Persepsi terhadap kemampuan adalah dimensi motivasi intrinsik ketiga terbanyak yang dimiliki anak $(80,0 \%)$.

\section{Strategi Pengaturan Diri dalam Belajar}

Hasil penilaian pada variabel strategi pengaturan diri dalam belajar siswa juga menunjukkan bahwa sebagian besar anak $(82,0 \%)$ memilih strategi effort regulation sebagai bentuk strategi pengaturan diri dalam belajar yang paling banyak digunakan. Effort regulation adalah kemampuan anak untuk menjaga perhatian, usaha dan komitmen ketika berhadapan dengan tugas-tugas yang sulit (Pintrich et al., 1991). Pada penelitian ini setiap dimensi strategi pengaturan diri dalam belajar dipilih oleh lebih dari separuh anak kecuali strategi organization. Organization adalah kemampuan anak di dalam memilih dan menyusun kembali informasi-informasi untuk dipelajari (Pintrich et al., 1991).

\section{Prestasi Akademik}

Prestasi akademik merupakan hasil akhir atau nilai yang diperoleh siswa pada satu periode waktu tertentu atau pada periode penyelesaian tugas tertentu di dalam proses pembelajaran merupakan salah satu cara untuk mengukur prestasi akademik siswa (Felts \& Grodsky, 2009). Penelitian ini menunjukkan bahwa hampir seluruh anak $(95,0 \%)$ memiliki prestasi akademik yang masuk ke dalam kategori baik, dengan rata-rata nilai Indeks Prestasi (IP) sebesar 3,15.

\section{Pengaruh Karakteristik Anak terhadap Harapan Orang tua dan Motivasi Intrinsik}

Hasil uji pengaruh menunjukkan bahwa karakteristik anak (jenis kelamin) tidak memiliki pengaruh terhadap harapan orang tua $(t<1,96)$ dan motivasi intrinsik $(t<1,96)$. Uji pengaruh dilakukan dengan asumsi bahwa orang tua memiliki harapan yang lebih tinggi pada anak perempuan dibanding anak laki-laki, dan anak perempuan memiliki motivasi intrinsik yang lebih tinggi dibanding anak laki-laki. Hasil penelitian menunjukkan bahwa orang tua cenderung memiliki harapan yang sama untuk anak laki-laki dan anak perempuan. Artinya, pada penelitian ini keragaman harapan orang tua tidak ditentukan oleh jenis kelamin anak. Penelitian ini menemukan bahwa anak laki-laki dan anak perempuan cenderung memiliki motivasi intrinsik yang sama. Artinya, pada penelitian ini jenis kelamin anak tidak dapat menjadi faktor penentu bagi keragaman motivasi intrinsik.

\section{Pengaruh Karakteristik Keluarga terhadap Harapan Orang tua}

Karakteristik keluarga (pendidikan orang tua) tidak memiliki pengaruh terhadap harapan orang tua $(t<1,96)$. Pendidikan orang tua dipilih sebagai indikator karakteristik keluarga karena memenuhi persyaratan untuk diuji pengaruh menggunakan PLS. Hasil penelitian menunjukkan bahwa pendidikan orang tua tidak dapat menjadi faktor penentu bagi keragaman harapan orang tua. Artinya, orang tua cenderung memiliki kepercayaan yang sama mengenai kesuksesan anak (harapan yang sama terkait kesuksesan anak) meskipun orang tua berasal dari latar belakang pedidikan yang berbeda-beda. 


\section{Pengaruh Harapan Orang tua terhadap Motivasi Intrinsik}

Hasil uji pengaruh menunjukkan bahwa motivasi intrinsik memiliki pengaruh terhadap harapan orang tua $(t>1,96)$. Pengaruh harapan orang tua terhadap motivasi intrinsik memiliki nilai $R$-square sebesar 0,22 . Artinya, keragaman motivasi intrinsik yang dapat dijelaskan oleh harapan orang tua adalah sebesar 22 persen, dan sisanya sebesar 78 persen dijelaskan oleh variabel lain di luar model penelitian. Hasil penelitian menunjukkan bahwa semakin orang tua mengekspresikan atau mengungkapkan harapannya kepada anak, maka motivasi intrinsik yang dimiliki anak akan semakin tinggi. Hal ini menunjukkan bahwa harapan orang tua yang tinggi akan mengarahkan anak untuk memiliki motivasi intrinsik yang tinggi pula.

\section{Pengaruh Motivasi Intrinsik terhadap Strategi Pengaturan Diri dalam Belajar}

Motivasi intrinsik memiliki pengaruh terhadap strategi pengaturan diri dalam belajar $(t>1,96)$. Pengaruh motivasi intrinsik terhadap strategi pengaturan diri dalam belajar memiliki nilai $R$-square sebesar 0,31. Artinya, keragaman strategi pengaturan diri dalam belajar yang dapat dijelaskan oleh motivasi intrinsik adalah sebesar 31 persen, dan sisanya sebesar 69 persen dijelaskan oleh variabel lain di luar model penelitian. Hasil penelitian menunjukkan bahwa semakin tinggi motivasi intrinsik, maka penggunaan strategi pengaturan diri dalam belajar akan semakin tinggi. Hal ini menunjukkan bahwa motivasi intrinsik yang tinggi akan mengarahkan anak untuk memiliki strategi pengaturan diri dalam belajar yang tinggi pula (memiliki kemampuan dan keterampilan yang tinggi dalam menggunakan strategi pengaturan diri).

Penelitian menunjukkan bahwa semakin tinggi motivasi intrinsik, maka penggunaan strategi pengaturan diri dalam belajar akan semakin tinggi. Hal ini menunjukkan bahwa motivasi intrinsik yang tinggi akan mengarahkan anak untuk memiliki strategi pengaturan diri dalam belajar yang tinggi pula (memiliki kemampuan dan keterampilan yang tinggi dalam menggunakan strategi pengaturan diri).

Pada penelitian ini diketahui bahwa motivasi intrinsik tidak hanya memiliki pengaruh langsung terhadap strategi pengaturan diri dalam belajar. Penelitian ini menemukan bahwa motivasi intrinsik berperan sebagai mediator bagi pengaruh harapan orang tua terhadap strategi pengaturan diri dalam belajar. Harapan orang tua memiliki pengaruh tidak langsung signifikan terhadap strategi pengaturan diri dalam belajar ( $t>1,96)$. Artinya, pengaruh tidak langsung harapan orang tua terhadap strategi pengaturan diri dalam belajar terjadi ketika harapan orang tua mampu meningkatkan motivasi intrinsik anak.

Pengaruh Karakteristik Anak dan Keluarga, Harapan Orang tua, Motivasi Intrinsik, dan Strategi Pengaturan Diri dalam Belajar terhadap Prestasi Akademik

Hasil uji pengaruh karakteristik anak dan keluarga, harapan orang tua, motivasi intrinsik, dan strategi pengaturan diri dalam belajar terhadap prestasi akademik menunjukkan bahwa hanya jenis kelamin ( $t>1,96)$ dan strategi pengaturan diri dalam belajar $(t>1,96)$ yang memiliki pengaruh terhadap prestasi akademik. Pengaruh karakteristik anak dan keluarga, harapan orang tua, motivasi intrinsik, dan strategi pengaturan diri dalam belajar terhadap prestasi akademik memiliki nilai $R$ square sebesar 0,24. Artinya, keragaman prestasi akademik yang dapat dijelaskan oleh karakteristik anak dan keluarga, harapan orang tua, motivasi intrinsik, dan strategi pengaturan diri dalam belajar adalah sebesar 24 persen, dan sisanya sebesar 76 persen dijelaskan oleh variabel lain di luar model penelitian. Hasil penelitian menunjukkan bahwa anak perempuan memiliki prestasi akademik yang lebih baik dibanding dengan anak laki-laki. Hasil penelitian juga menunjukkan bahwa semakin baik penggunaan strategi pengaturan diri dalam belajar oleh anak, maka akan meningkatkan prestasi akademik anak.

Pada penelitian ini diketahui bahwa strategi pengaturan diri dalam belajar tidak hanya memiliki pengaruh langsung terhadap prestasi akademik. Penelitian ini menemukan bahwa strategi pengaturan diri dalam belajar berperan sebagai mediator bagi pengaruh harapan orang tua dan motivasi intrinsik terhadap prestasi akademik. Hasil penelitian menunjukkan bahwa harapan orang tua ( $t$ $>1,96)$ dan motivasi intrinsik ( $t>1,96)$ memiliki pengaruh tidak langsung signifikan terhadap prestasi akademik. Model akhir pengaruh harapan orang tua, motivasi intrinsik, dan strategi pengaturan diri dalam belajar terhadap prestasi akademik disajikan pada Gambar 1. 


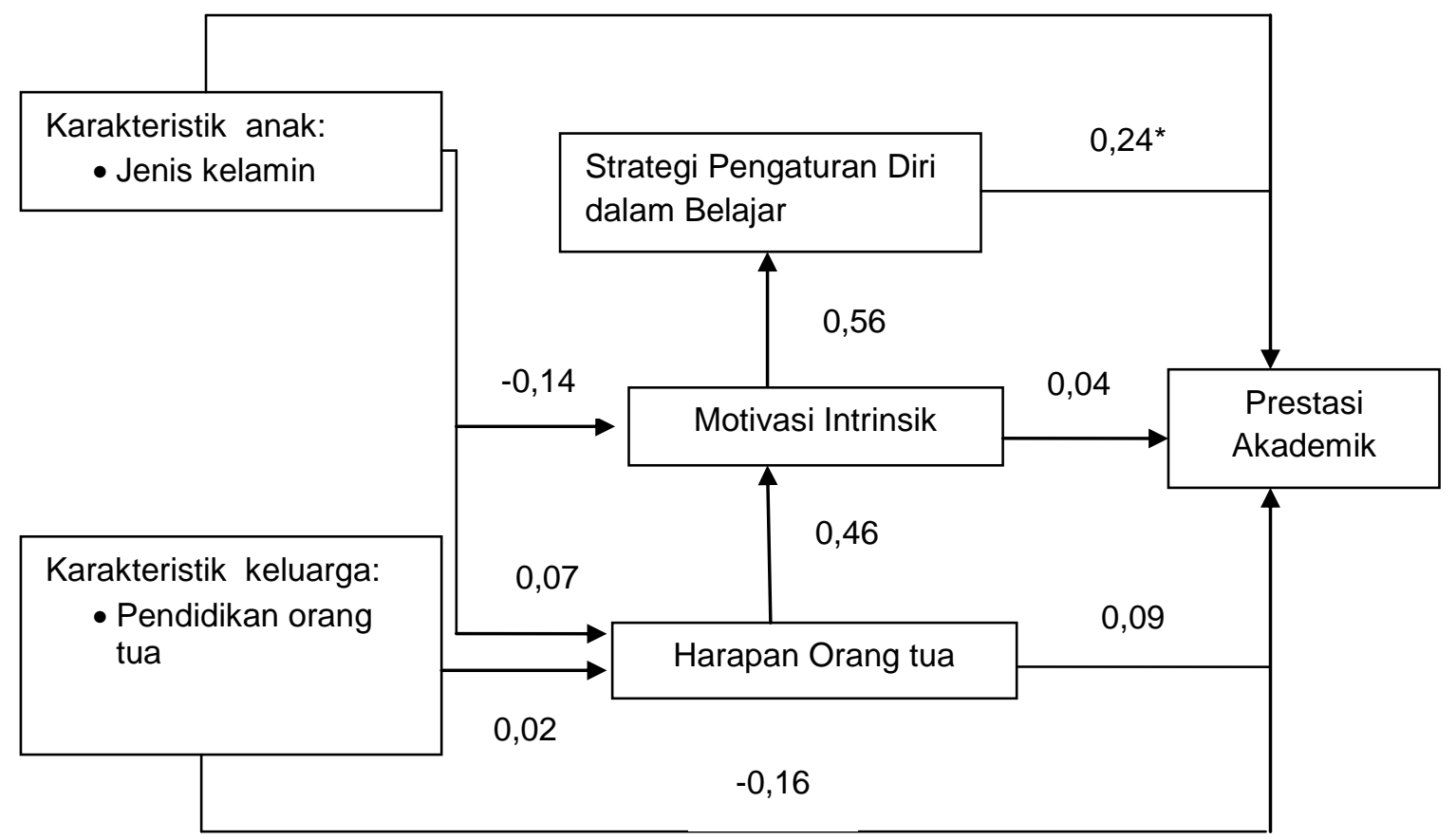

Gambar 1 Model analisis pengaruh harapan orang tua, motivasi intrinsik, dan strategi pengaturan diri dalam belajar terhadap prestasi akademik

\section{PEMBAHASAN}

Hasil penelitian menunjukkan bahwa jenis kelamin anak tidak berpengaruh terhadap harapan orang tua dan motivasi intrinsik. Sejalan dengan hasil penelitian Marcus dan Corsini (1978) yang menyatakan bahwa ibu memiliki harapan terhadap masa depan yang relatif sama pada anak laki-laki dan perempuan. Hasil penelitian Tariq et al. (2011) menyatakan bahwa tidak ada perbedaan motivasi intrinsik antara anak laki-laki dan anak perempuan. Hal ini mungkin dikarenakan pada penelitian ini harapan orang tua dan motivasi intrinsik lebih dipengaruhi oleh karakteristik demografi anak seperti urutan kelahiran dan usia anak. Hasil penelitian Hao dan BonsteadBruns (1998) menyatakan bahwa urutan kelahiran memiliki pengaruh terhadap harapan orang tua. Orang tua memiliki harapan yang lebih tinggi pada anak yang lebih tua. Hasil penelitian Gillet et al. (2012) menyatakan bahwa usia anak memiliki pengaruh terhadap motivasi intrinsik. Motivasi intrinsik menurun ketika anak berusia 9-12 tahun, dan secara perlahan mulai stabil sampai anak berusia 15 tahun yang diikuti peningkatan motivasi intrinsik setelah anak berusia 15 tahun.
Jenis kelamin memiliki pengaruh signifikan positif secara langsung terhadap prestasi akademik. Hasil penelitian ini sejalan dengan penelitian Yousefi et al. (2010) yang memperlihatkan adanya perbedaan yang signifikan antara anak perempuan dengan anak laki-laki dalam pencapaian prestasi akademik. Anak perempuan memiliki prestasi akademik yang lebih tinggi dibandingkan anak laki-laki. $\mathrm{Di}$ sisi lain, hasil penelitian Naderi et al. (2009) tidak menemukan adanya perbedaan yang signifikan antara anak perempuan dengan anak laki-laki dalam prestasi akademik. Caprara et al. (2008) menyatakan bahwa dibandingkan dengan anak laki-laki, anak perempuan cenderung memiliki persepsi yang tinggi terhadap kemampuan pengaturan diri dalam aktivitas akademik sehingga anak perempuan menunjukkan penurunan perkembangan yang cenderung lebih sedikit dalam pendidikan dibandingkan dengan anak laki-laki. Griffin et al. (2012) menyatakan bahwa perbedaan gender dalam prestasi akademik dimediatori oleh keterampilan dan kemampuan penggunaan strategi di dalam belajar. Jenis kelamin tidak akan berpengaruh terhadap prestasi akademik ketika keterampilan dan kemampuan penggunaan strategi di dalam 
belajar tidak diperhatikan dan hanya masuk sebagai variabel kontrol.

Pendidikan orang tua tidak berpengaruh terhadap harapan orang tua. Hoover-Dempsey dan Sandler (1997) menuliskan bahwa status sosial-ekonomi keluarga tidak selalu muncul sebagai faktor yang dapat menentukan nilai yang dimiliki orang tua terkait pendidikan anak. berbeda dengan hasil penelitian yang dilakukan oleh Kaplan et al. (2001) dan Jacob (2010) bahwa pendapatan dan pendidikan orang tua berpengaruh terhadap harapan orang tua. Hasil ini diduga karena pada penelitian ini harapan orang tua lebih dipengaruhi oleh karakteristik demografi keluarga. Hasil penelitian Hao dan Bonstead-Bruns (1998) menyatakan bahwa interaksi orang tua-anak dalam aktivitas pembelajaran memiliki pengaruh positif terhadap harapan orang tua. Interaksi orang tua-anak berperan penting dalam mentransmisikan harapan orang tua kepada anak, sehingga dapat meningkatkan kesepakatan dan menurunkan perbedaan orang tua-anak.

Penelitian ini membuktikan bahwa harapan orang tua memiliki pengaruh langsung positif terhadap motivasi intrinsik. Sejalan dengan hasil penelitian yang dilakukan Yang, Tseng, dan Lin (2012) bahwa harapan orang tua berfungsi sebagai sebuah bentuk komunikasi nilai yang dimiliki orang tua kepada anak mengenai kemampuan dan kompetensi anak. Harapan orang tua yang dikomunikasikan kepada anak akan meningkatkan keyakinan anak terhadap kemampuan dan kompetensi yang dimilikinya (Yamamoto \& Holloway, 2010). Hasil penelitian menunjukkan lebih dari separuh anak mempersepsikan bahwa orang tua cukup memiliki harapan terhadap kesuksesan anak di masa depan dan anak memiliki motivasi intrinsik yang cukup untuk terlibat di dalam suatu aktivitas. Harapan orang tua disebut juga sebagai second-order expectations yaitu harapan orang lain yang dipegang oleh individu sehingga harapan orang tua dapat bertindak sebagai faktor eksternal yang dapat menyebabkan anak terlibat dalam suatu aktivitas. Berdasarkan teori self-dertermination, motivasi ekstrinsik dapat berubah menjadi motivasi intrinsik melalui beberapa tingkatan proses, yaitu: 1) external, yaitu pengaturan datang dari luar diri individu, 2) introjected, yaitu pengaturan internal yang didasarkan pada perasaan bahwa individu harus melakukan suatu perilaku, 3) identified, yaitu pengaturan internal yang didasarkan pada kegunaan dari perilaku, dan 4) integrated, yaitu pengaturan yang didasarkan pada apa yang dianggap individu berharga dan penting untuk dirinya (Eccles \& Wigfiels, 2002). Usaha anak dalam menginternalisasikan harapan orang tua dapat mengubah harapan orang tua dari pengaturan yang berasal dari luar diri anak (motivasi ekstrinsik) menjadi pengaturan yang berasal dari dalam diri anak (motivasi intrinsik).

Penelitian ini menemukan bahwa harapan orang tua memiliki pengaruh tidak langsung yang signifikan terhadap strategi pengaturan diri dalam belajar. Motivasi intrinsik berperan sebagai mediator bagi pengaruh harapan orang tua terhadap strategi pengaturan diri dalam belajar. Harapan orang tua memiliki pengaruh tidak langsung yang signifikan terhadap prestasi akademik. Motivasi intrinsik dan strategi pengaturan diri dalam belajar berperan sebagai mediator bagi pengaruh harapan orang tua terhadap prestasi akademik. Harapan yang dimiliki orang tua berhubungan dengan harapan pribadi dan harapan karir. Harapan pribadi adalah harapan orang tua mengenai bagaimana anak seharusnya berperilaku. Harapan karir adalah harapan orang tua mengenai masa depan anak (Sasikala \& Karunanidhi, 2011). Orang tua akan mendorong anak untuk melakukan hal sebaik mungkin, mengajarkan anak untuk melakukan sesuatu sesuai keinginan, dan membentuk perilaku yang mengarahkan pada pencapaian prestasi. Kemandirian yang diberikan kepada anak merupakan faktor penting untuk mengembangkan kemampuan pengaturan diri anak (Sui-Chu, 2004).

Motivasi intrinsik memiliki pengaruh langsung positif terhadap strategi pengaturan diri dalam belajar. Sejalan dengan hasil penelitian Pintrich dan De Groot (1990). Siswa yang termotivasi secara intrinsik akan mencari informasi dalam menyelesaikan tugas, mencari bantuan ketika menghadapi kesulitan, serius dalam memilih dan menggunakan strategi pengaturan diri dalam belajar yang sesuai, serta menjaga tingkat ketertarikan yang tinggi terhadap materi pelajaran (Metallidou \& Vlachou, 2010). Motivasi intrinsik merupakan komponen penting dalam melihat kecenderungan siswa dalam menggunakan 
strategi pengaturan diri dalam belajar. Keterlibatan siswa dalam penggunaan strategi pengaturan diri dalam belajar berkaitan erat dengan kepercayaan mereka bahwa proses pembelajaran adalah kegiatan yang menyenangkan dan berharga (Pintrich \& De Groot, 1990). Hubungan motivasi intrinsik dan penerapan strategi pengaturan diri dalam belajar terlihat ketika siswa dapat menikmati apa yang dilakukan dan merasa memiliki kontrol terhadap proses pembelajaran (Nakata, 2010). Berdasarkan teori social-cognitive, motivasi siswa berhubungan secara langsung dengan kemampuan siswa dalam mengatur aktivitas belajar. Motivasi siswa akan berubah dari satu materi pelajaran ke materi pelajaran lainnya (motivasi bersifat dinamis). Pada penelitian ini anak mempersepsikan bahwa usaha atau prioritas merupakan bentuk dari motivasi intrinsik yang menyebabkan mereka terlibat di dalam suatu aktivitas pembelajaran, dan sebagian besar anak mempersepsikan bahwa effort regulation adalah strategi pengaturan diri dalam belajar yang sering digunakan. Motivasi seseorang dapat diduga dari banyaknya usaha yang telah diperlihatkannya. Usaha ini akan meningkatkan motivasi individu yang pada akhirnya akan membuat seseorang pantang menyerah dalam menghadapi tugas yang sulit (salah satu bentuk effort regulation).

Hasil penelitian menemukan bahwa motivasi intrinsik memiliki pengaruh tidak langsung yang signifikan terhadap prestasi akademik. Strategi pengaturan diri dalam belajar berperan sebagai mediator bagi pengaruh motivasi intrinsik terhadap prestasi akademik. Metallidou dan Vlachou (2010), Stegers-Jager et al. (2012), dan Liao et al. (2012) menuliskan bahwa strategi pengaturan diri dalam belajar berperan sebagai mediator bagi pengaruh motivasi intrinsik terhadap prestasi akademik. Hal ini menunjukkan bahwa motivasi saja tidak dapat berkontribusi terhadap prestasi akademik siswa tanpa adanya strategi pengaturan diri dalam belajar. Tingginya motivasi intrinsik yang dimiliki siswa akan mengarahkannya pada penerapan strategi pengaturan diri dalam belajar yang tinggi. Penerapan strategi pengaturan diri dalam belajar yang tinggi ini akan membawa siswa mencapai prestasi akademik yang tinggi. Eccles dan Wigfiels (2002) menuliskan bahwa motivasi intrinsik yang tinggi berperan dalam memfasilitasi penggunaan strategi belajar yang sesuai dan prestasi akademik yang tinggi.
Strategi pengaturan diri dalam belajar memiliki pengaruh langsung positif terhadap prestasi akademik. Hasil penelitian ini sejalan dengan hasil penelitian yang dilakukan oleh Thongnoum (2002), Stegers-Jager et al. (2012), dan Liao et al. (2012). Strategi pengaturan diri dalam belajar berfokus pada bagaimana siswa menginisiasi, memonitor, dan mengontrol pembelajarannya sendiri (Metallidou \& Vlachou, 2010). Keefektifan penggunaan strategi pengaturan diri dalam belajar tergantung pada kuantitas dan kualitas interaksi antara siswa dengan materi pelajaran (Salmeron-Perez et al., 2010). Kriteria siswa yang menerapkan strategi pengaturan diri dalam belajar, yaitu: (1) pantang menyerah dalam menghadapi tugas yang sulit, (2) penuh strategi dan pandai dalam mengahadapi tantangan, dan (3) bereaksi atau memberikan umpan balik terhadap hasil kerja (Thongnoum, 2002). Pada penelitian ini sebagian besar anak menggunakan effort regulation sebagai strategi pengaturan diri dalam belajar, dan hampir seluruh anak memiliki prestasi akademik yang masuk ke dalam kategori baik. Manajemen usaha memiliki peranan penting bagi kesuksesan secara akademik karena tidak hanya menunjukkan komitmen terhadap tujuan, tetapi juga mengatur penggunaan terus-menerus strategi di dalam belajar (Pintrich et al., 1991). Effort regulation yang diterapkan anak di dalam belajar memiliki pengaruh yang signifikan terhadap peningkatan prestasi akademik.

Sui-Chu (2004) dan Liao et al. (2012) menuliskan bahwa strategi pengaturan diri dalam belajar adalah proses dan aktivitas yang dapat diinisiasikan oleh orang lain selain diri siswa. Strategi pengaturan diri dalam belajar tidak semata-mata dilihat sebagai proses di dalam diri (kemampuan dan pengetahuan siswa), tetapi juga sebagai proses yang dipengaruhi secara timbal balik oleh lingkungan dan perilaku. Konteks sosial dan interaksi sosial memiliki peranan penting di dalam pengembangan strategi pengaturan diri dalam belajar, sehingga strategi pengaturan diri dalam belajar berkembang karena adanya interaksi antara individu dengan konteks sosial. Hasil penelitian ini membuktikan bahwa meskipun strategi pengaturan diri dalam belajar memiliki peranan yang besar bagi prestasi akademik, tetapi interaksi antara harapan orang tua dan motivasi intrinsik anak dalam pengembangan strategi pengaturan diri dalam belajar tidak dapat diabaikan. 


\section{SIMPULAN DAN SARAN}

Jenis kelamin tidak memiliki pengaruh terhadap harapan orang tua dan motivasi intrinsik. Pendidikan orang tua tidak memiliki pengaruh terhadap harapan orang tua. Motivasi intrinsik dipengaruhi oleh harapan orang tua, dan motivasi intrinsik memiliki pengaruh terhadap strategi pengaturan diri dalam belajar. Prestasi akademik dipengaruhi oleh jenis kelamin dan strategi pengaturan diri dalam belajar. Strategi pengaturan diri dalam belajar berperan sebagai mediator bagi pengaruh harapan orang tua dan motivasi intrinsik terhadap prestasi akademik. Strategi pengaturan diri dalam belajar lebih berperan besar terhadap peningkatan prestasi akademik karena perannya sebagai mediator bagi pengaruh variabel lain terhadap prestasi akademik.

Hasil penelitian menunjukkan bahwa strategi pengaturan diri dalam belajar memiliki peranan yang besar dalam peningkatan prestasi akademik. Berdasarkan hal tersebut, anak perlu diajarkan mengenai cara menerapkan strategi pengaturan diri dalam belajar yang efektif di dalam setiap proses pembelajaran. Hal ini dapat dilakukan oleh pihak sekolah dengan menerapkan kebijakan pelatihan pengembangan kemampuan siswa dalam menggunakan strategi pengaturan diri dalam belajar di setiap tahun ajaran baru. Guru dapat membantu siswa meningkatkan kemampuan penggunaan strategi pengaturan diri dalam belajar dengan menciptakan kegiatan atau lingkungan pembelajaran yang meningkatkan keterlibatan, membangun rasa keingintahuan, dan menarik minat siswa (lingkungan pembelajaran yang meningkatkan motivasi intrinsik siswa).

Peran harapan orang tua terhadap pengembangan strategi pengaturan diri dalam belajar memperlihatkan bahwa orang tua juga memiliki peranan penting di dalam pengembangan strategi pengaturan diri dalam belajar. Hal yang dapat dilakukan orang tua adalah dengan meningkatkan interaksi orang tua-anak dalam lingkungan belajar seperti membantu dan membimbing anak dalam mengerjakan tugas sekolah, mengawasi aktivitas anak setelah pulang sekolah, mendorong anak untuk melakukan suatu hal dengan baik, dan mengajarkan anak untuk melakukan sesuatu berdasarkan keinginannya sendiri. Orang tua perlu memberikan anak akses terhadap berbagai kesempatan dan dukungan yang dibutuhkan anak.

\section{DAFTAR PUSTAKA}

Agliata, A. K. (2005). College students' wellbeing: The role of parent-college student expectation discrepancies and communication (disertasi). University of Central Florida, Florida.

[BPS] Badan Pusat Statistik. (2011). Provinsi Jawa Barat. Diambil dari: www.jabar.bps.go.id/subyek/jumlah-danpresentase-penduduk-miskin-dan-gariskemiskinan-menurut-kabupatenkota-2011. [diunduh 15 Mei 2014].

Caprara, G. V., Fida, R., Vecchione, M., Del Bove, G., Vecchio, G. M., Barbaranelli, C., \& Bandura, A. (2008). Longitudinal analysis of the role of perceived selfefficacy for slf-regulated learning in academic and achievement. Journal of Education Psychology, 100(3), 525-534. doi: 10.1037/0022-0663.100.3.525.

Eccles, J. S., \& Wigfield, A. (2002). Motivational beliefs, values, and goals. Annu. Rev. Psychol. 53, 109-132.

Felts, E., \& Grodsky, E. (2009). Academic achievement. Di dalam: Carr D. Encyclopedia of the Life Course and Human Development 1. Detroit, US: Macmillan.

Friedenberg, L., \& Breckenridge, L. J. (2005). Adolescence: Cognitive skills. Di dalam: Piotrowski NA. Psychology Basics (Vol 1). California, US: Salem Pr.

Gillet, N., Vallerand, R. J., \& Marc-Andre, K. L. (2012). Intrinsic and extrinsic school motivation as a function of age: The mediating role of autonomy support. Soc Psychol Educ, 15, 77-95. doi: 10.1007/s11218-011-9170-2.

Griffin, R., MacKewn, A., Moser, E., \& VanVuren, K. W. (2012). Do learning and study skills affect academic performance? An empirical investigation. Contemporary Issues In Education Research-Second Quarter, 5(2).

Hao, L., \& Bonstead-Bruns, M. (1998). Parentchild differences in educational expectations and academic achievement of immigrant and native students. Sociology of Educational, 71(3),175-198. 
Hoover-Dempsey, K. V., \& Sandler, H. M. (1997). Why do parents become involved in their children's education?. Review of Educational Research, 67(1).

Jacob, M. J. (2010). Parental expectations and aspirtations for their children's educational attainment: An examination of the collegegoing mindset among parents (disertasi). University of Minnesota, Minnesota.

Kaplan, D. S., Liu, X., \& Kaplan, H. B. (2001). Influence of parents' self-feelings and expectations on children's academic performance. The Journal of Education Research, 96(6).

Liao, H. A., Ferdenzi, A. C., \& Edlin, M. (2012). Motivation, self-regulated learning efficacy, and academmic achievement among international and domestic students at an urban community college: A comparison. The Community College Enterprise, 18(2), 9-38.

Marcus, T. L., \& Corsini, D. A. (1978). Parental expectations of preschool children as related to child gender and socio economic status. Child Development, 49, 243-246.

Metallidou, P., \& Vlachou, A. (2010). Children's self-regulated learning profile in language and mathematics: The role of task value beliefs. Psychology in the Schools, 47(8). doi: 10.1002pits.20503.

Naderi, H., Abdullah, R., Aizan, H.T., Sharir, J., \& Kumar, V. (2009). Creativity, age and gender as predictors of academic achievement among undergraduate students. Journal of American Science, 5(5), 101-112.

Nakata, Y. (2010). Toward a framework for selfregulated langiage-learning. TESL Canada Journal, 27(2).

Novariandhini, D. A., \& Latifah., M. (2012). Harga diri, efikasi diri, motivasi belajar, dan prestasi akademik siswa SMA pada berbagai model pembelajaran. Jurnal IImu Keluarga dan Konsumen, 5(2). 138-146.

[OECD] Organisation for Economic Cooperation and Development. (2012). What students know and can do: Student performance in mathematics, reading and science. Diambil dari: www.oecd.org/pisa/keyfindings/PISA2012-results-snapshot-Volume-I-ENG.pdf. [diunduh 6 Mar 2014].
[Permendikbud] Peraturan Menteri Pendidikan dan Kebudayaan. (2013). Permendikbud No 81 A tahun 2013 tentang implementasi kurikulum. Diambil dari urip.files. wordPr.com. [diunduh 27 Mei 2014].

Pintrich, P. R., \& De Groot, E. V. (1990). Motivational and self-regulated learning components of classroom academic performance. Journal of Educational Psychology, 82(1), 33-40.

Smith, D. A. F., Garcia, T., \& McKeachie, W. J. (1991). A manual for the use of the Motivated Strategies for Learning Questionnaire (MSLQ). Ann Arbor: University of Michigan, National Center for Research to Improve Postsecondary Teaching and Learning.

Salmeron-Perez, H., Gutierrez-Braojos, C., Fernande-Cano, A., \& Salmeron-Vilche, P. (2010). Self-regulated learning, selfefficacy beliefs and performance during the late childhood. Relieve, 16(2),1-18.

Sasikala, S., \& Karunanidhi, S. (2011). Development and validation of perception of parental expectations inventory. Journal of Indian Academy of Applied Psychology, 37(1), 114-124.

[SDT] Self Determination Theory. (2014). Intrinsic motivation inventory (IMI). Diambil dari: www. Selfdetermination-theory.org/ questionnaires. [diunduh 6 Mar 2014].

Sui-Chu, E.H. (2004). Self-regulated learning and academic achievement of Hong Kong secondary school students. Educational Journal, 32(2).

Stegers-Jager, K. M., Cohen, S. J., \& Themmen, A. P. N. (2012). Motivational, learning strategies, participation and medical school performance. Medical Education, 46, 678-688.

Tariq, S., Mubeen, S., \& Mahmood, S. (2011). Relationship between intrinsic motivation and goal orientation among college students in Pakistani context. Journal of Education and Paractice, 2(10).

Thongnoum, D. (2002). Self-efficacy, goal orientations, and self-regulated learning in Thai students (disertasi). Oklahoma State University, Oklahoma.

Weiss, C., (2008). Education, Academic Performance. Di dalam: Parrilo VN. 
Encyclopedia of Social Problems (Vol 1). California, US: Sage.

Yamamoto, Y., \& Holloway, S. D. (2010). Parental expectations and children's academic performance in sociocultural context. Educ Psycol Rev, 22, 189-214. doi: 10.1007/s10648-010-9121-z.

Yang, F. Y., Tseng, J.S., \& Lin, M.H. (2012). The interaction between junior-high students' academic and social motivations and the influences of the motivational factors on science performance. The Asia-
Pacific Education Researcher, 21(1), 92106.

Yousefi, F., Bte Mansor, M., Bte Juhari, R., Redzuan, M., \& Talib, A. M. (2010). The relationship between gender, age, depression and academic achievement. Current Research in Psychology, 1(1), 6166.

Zimmerman, B. J. (1990). Self-regulated learning and academic achievement: An overview. Educational Psychologist, 25(1), 3-17. 